\title{
ENYEDI GYÖRGY, A „MESTER”
}

Születésnapod alkalmából a Regionális Tudományos Bizottság tagjai nevében sok szeretettel köszöntelek, elsősorban azok nevében, akik mesterként tekintenek rád.

Miért választottam köszöntőm címében a „mestert”, így, idézőjelben? Holott a Bizottság tagjainak többségéhez hasonlóan nem voltam az egyetemi tanítványod, nem vizsgáztam nálad, nincs közös cikkünk, nagyobb közös kutatásban sem vettünk együtt részt. Munkahelyi függőségi viszony is csak 1986-1994 között volt köztünk, amikor főigazgatóként felvettél tudományos segédmunkatársnak a Regionális Kutatások Központja békéscsabai osztályára.

Mégis tanítványodnak vallom magam, Enyedi-tanítványnak, azaz mesteremnek tartalak, ha ezzel nem sértelek meg. Mit jelent a mester? Erre a kérdésre az általam is naponta végzett kundalíni jóga megalapítójának, Yogi Bhajan-nak egyik idézetével válaszolok:

„Ha szeretnél megtanulni valamit, olvass róla.

Ha szeretnél megérteni valamit, írjál róla.

Ha valaminek a mestere szeretnél lenni, azt tanítsd...

Mások tanítása és tudatuk felemelése

A Te tudatodat emeli és tanítja."

Egy tudományos kutatónak nem elég csak olvasni, vizsgálódni és publikálni az eredményeket, hanem tanítani kell, át is kell adni mások számára a tudást. Nemcsak a tanítványok ismeretszintjét, hanem a tudatukat is emelni kell: követendő mintát, példát kell nyújtani. Úgy vélem, hogy tanítványaid számára ez a legértékesebb: követendő példát adtál egyéniséged, viselkedésed, emberi magatartásod révén.

Milyen követendő mintát kaptunk a mestertől? Hármat emelek ki: empátiát és toleranciát, a minőségi teljesítmény tiszteletét, valamint a tanítványok kezdeményezéseinek megértő segítését.

Empátiát és toleranciát tanultunk töled, ami a tudományos vitákhoz, a tỏlünk eltérő vélemények tiszteletéhez elengedhetetlen. Számomra meghatározó volt, amikor 1994-ben elhagytam az RKK-t, nem orroltál meg érte, pedig többen árulásnak tartották. Amikor az intézetben dolgozva, még 1991 tavaszán kiléptem az Alföldprogramból, bizonyos szakmai összezörrenések miatt, először megfedtél, de azután elfogadtad lépésemet és továbbra is támogattál, rögtön egy nemzetközi szervezet, az IGU egyik munkabizottságába delegáltál magad helyett. Amint személyes példám is mutatja, pozitívan álltál a dolgainkhoz, empátiával szemlélted tevékenységünket, toleráltad csetléseinket és botlásainkat, ezáltal többletenergiát nyújtottál. Nem a 
hibákra és a tévedésekre figyeltél, hanem azokat is szóvá téve, de pozitív szemlélettel a legjobbat próbáltad kihozni belölünk.

A minöségi teljesitmény tiszteletét vettük át töled. A nívós tudományos teljesítményt elismerted, lehetőséget adtál nemzetközi és hazai kapcsolataid révén, hogy az eredményeket felmutatók bekerülhessenek a szakmai közösségekbe. Sokat segítettél színvonalas tanulmányok publikálásában, nemcsak felhívtad a figyelmet az eredmények közlésének fontosságára, hanem segítettél a publikációs fórumok, konferenciák, folyóiratok kiválasztásában is. Saját pályámon is meghatározó volt útmutatásod, az intézetbe kerülve javasoltad és támogattad, hogy az akkori tanácsok, a későbbi önkormányzatok gazdálkodásával foglalkozzak, részben ebből született meg kandidátusi értekezésem. Majd később, amikor tépelődtem, hogy a regionális versenyképesség kutatásával érdemes-e foglalkozni, a veled történt beszélgetés eldöntötte, és ez lett a témája az MTA doktori értekezésemnek is.

A tanitványok kezdeményezéseinek megértő segitését. Tanácsaiddal, egy-egy iránymutató megjegyzéseddel ösztönözted, hogy a fiatalok által felvetett kezdeményezések közül az arra érdemesek kibontakozhassanak. Érvényesülésünket megértő módon segítetted, a különböző pályázatoknál mindig számíthattunk ajánlásodra, támogatásodra. Pl. az életpályám alakulásában fontos Széchenyi-professzori ösztöndíj, tanszékvezetői pályázat elnyerésében, és még hosszan sorolhatnám, az ajánlásod fontos szerepet töltött be. De ugyanígy az Akadémiai Kiadó 'modern regionális tudomány' könyvsorozat ötletét kezdetektől támogattad, elfogadtad a sorozat tanácsadó bizottsági tagságát, ami döntő érvnek bizonyult a kiadó meggyőzésében.

Mit köszönhet a Regionális Tudományos Bizottság Enyedi Györgynek? Ha az túlzásnak is hat, hogy mindent, de a Bizottság létrehozója, 1986-os megalapítója és első elnöke. Akkor 17 főből állt a Bizottság köztestületi tagsága, most 86 fős, akik 16 egyetemen és főiskolán, továbbá 4 kutatóintézetben dolgoznak. Habár regionális tudománnyal foglalkozó bizottságok átmenetileg korábban is müködtek, de a Te munkásságodhoz köthető a hazai szakma intézményesülése, a Regionális Kutatások Központja létrehozása, a Tér és Társadalom folyóirat elindítása, hogy jogunk van regionális tudományból is MTA doktora címet szerezni, PhD-fokozatot kiadni stb. A regionális tudományban elnyert kandidátusi, MTA doktori címek többségének menedzselésében meghatározó szereped volt, van. Mint bizottsági elnök látom, hogy az igen heterogén MTA IX. Gazdaság- és Jogtudományok Osztályán folyó 'birkózásban' milyen bölcs türelemmel és kitartással képviseled szakmánkat. 
Kedves Gyuri, köszönjük, hogy mesterként megértően segítettél minket tudományos pályánkon, elfogadtál olyannak minket, amilyenek vagyunk, hibáinkkal és gyarlóságainkkal együtt. Megpróbáljuk a saját tanítványainknak átadni, amit tőled kaptunk és kapunk: az empátiát és toleranciát, a minőségi teljesítmény tiszteletét és a tanítványok kezdeményezéseinek megértő segítését.

Éltessen az Isten még sokáig, erőben, egészségben.

Lengyel Imre

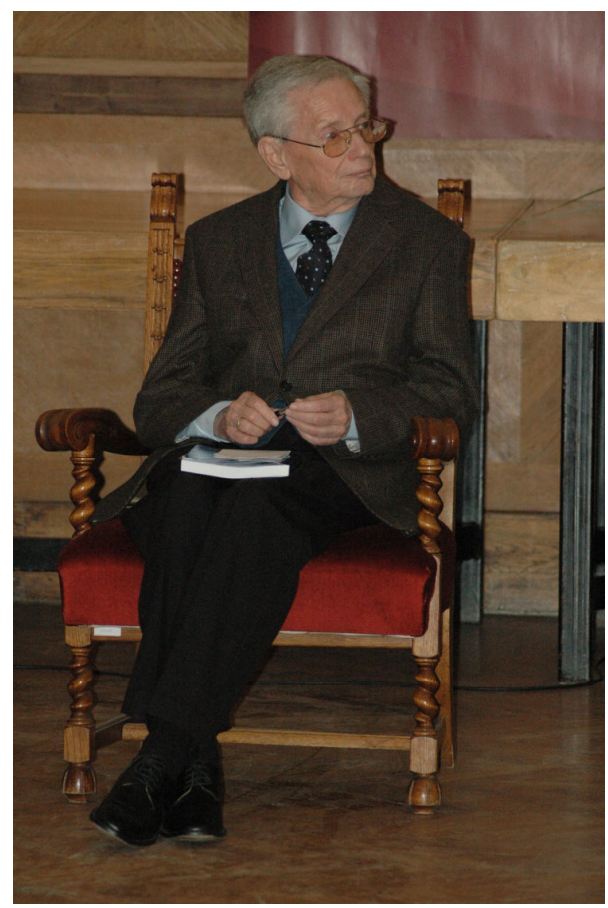

Fotó: Hardi Tamás. 


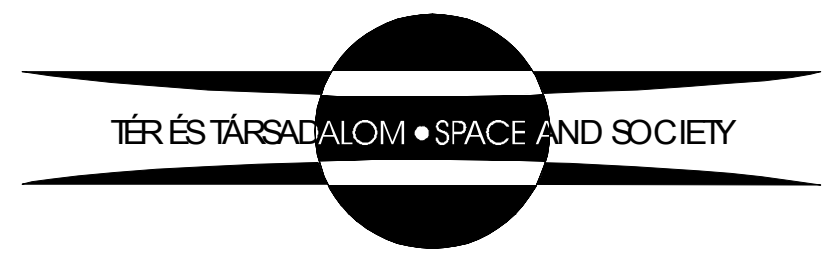

